\title{
Agencification in Asia: \\ Lessons from Thailand, Hong Kong, and Pakistan
}

\author{
Arif Budy Pratama \\ Public Administration program, Universitas Tidar \\ arifpratama@untidar.ac.id
}

\begin{abstract}
This paper discusses the agencification phenomena as one of New Public Management (NPM)based administrative reform initiatives. Thailand, Hong Kong, and Pakistan were chosen because of their similarity on administrative legacy and availability of data. The study uses a review of literature research method, while comparative approach was employed to analyze experiences of agencification in the three selected cases. Research result showed that the three countries implemented agencification in different ways; rational agency model is not the only driver for agencification initiatives; and contextual factor that include traditions, cultures, structures, and values influence the implementation of agencification process as a public sector reform initiative. Policy implications can be drawn by reading the three countries on agencification. Thus, Indonesia, as one of NPM adopters can learn from experience gleaned from the three polities in conducting its administrative reform agenda.
\end{abstract}

Keywords: administrative reform, agencification, NPM 


\section{INTRODUCTION}

The creation of agencies has been one of the megatrends in New Public Management (NPM)-based administrative reform. The increasing number of agencies in many countries (James, 2003; Jordana, Levi-Faur, \& i Marin, 2011; Pollit, Bathgate, Caulfield, Smullen, \& Talbot, 2001; Smullen, 2007; Verhoest, van Thiel, Bouckaert, \& Lægreid, 2012) and supra-national level (BUSUIOC, 2016; Egeberg \& Trondal, 2016; Ongaro, Barbieri, Belle, \& Fedele, 2012) shows how this idea has been spreading around the globe.

This form of organizing is known as agencification, which refers to the establishment of autonomous bodies within the framework of performance contract-based result control instead of political intervention as the main feature. This is in line with the essence of reengineering, which is based on the premise of altering outdated rule and replacement with a new one (Muchiri, 1999) the agencification can also be categorized as public organization reengineering. The process of reengineering is aimed transform and minimize outdated-hierarchical mechanism and change public organizations become flatter and more efficient.

During the zenith of the popularity of the NPM paradigm, governments were confident that the creation of agencies that were detached or separated from parent ministries would generate economic, institutional, and political benefits (Pollitt \& Talbot, 2003; Pollitt, Talbot, Caulfield, \& Smullen, 2004; Verhoest et al., 2012).

Similar to other doctrines such as privatization, agencification soon became a buzzword in public administration reform literature and practice (Wettenhall, 2005). Many developing countries especially in Asia, immediately jumped on the bandwagon to adopt agencification as a reform agenda. Thailand, Hong Kong, and Pakistan are chosen as the locus of this study for two reasons. Firstly, both Hong Kong and Pakistan have British legacy in their administrative system and Thailand is perceived to be one of South East Asian countries that adopted NPM agencification (Haque, 2013). To that end, the case studies have a wealth of experience in the realm of agencification, albeit in varied forms. Accordingly, the three case studies are considered to be representatives of countries that follow individualist management ideologies adopted from Anglophone countries such as the the UK, the US, Australia, and New Zealand. Secondly, the availability of data and research reports, sourced from Comparative Public Organization Data Base for Research (COBRA) Project allows the author to conduct a comparative analysis among them since the three used a similar framework.

Whilst, the COBRA report (Verhoest et al, 2012) analyzes 30 countries in broader contexts, this essay aims to conduct an indepth report on Thailand, Hong Kong, and Pakistan. The three case studies were chosen to reflect the Asian perspective on agencification.

The paper begins with a discussion of theoretical aspects and debates of agencification, which is aimed at obtainining a comprehensive understanding of agencification. Subsequently, empirical studies and experiences of some selected countries from literature will be presented and compared based on the main aspect of agencification. This comparative analysis showed that the NPM agency model is not the only major factor that is perceived to be the driving force of agencification, but also contextualization and localism also play an important role in the agencification process in the three countries studied. In the discussion section, I will analyze major findings of the three case studies from which Indonesia can draw lessons from their experiences.

\section{RESEARCH METHODS}

This study used literature review as the main research method. Data were drawn from Comparative Public Organization Data Base for Research (COBRA) on agencification, which is documented in Verhoest et al (2012) that compares agencification process in 30 countries. The literature review process was conducted through a snowball technique and considered all the works published in relation to the major themes of the study that included agency, agencification, semiautonomous agency, Thailand, Hong Kong, and Pakistan. 
With regards to agencification process in Thailand, empirical case studies conducted by Bowornwathana (2012) which drawn from COBRA project were the main literature source. While, supporting literature were obtained from Autonomisation of the Thai state: Some observations (Bowornwathana, 2006) and Autonomy and Performance of Agentification: Cases of Nine Independent Agencies in Thailand (Lorsuwannarat 2014).

Meanwhile, for the case of agencification in Hong Kong, empirical case studies that were conducted by Painter (2012) (also part of COBRA project) served as the main literature source. To supplement the main literature sources, other articles were used that included Coordinating the government bureaucracy in Hong Kong: An institutional analysis (Lam, 2005); Budgetary reforms in two city states: impact on the central budget agency in Hong Kong and Singapore (Cheung, 2006); The new public management reform and governance in Asian NICs: A comparison of Hong Kong and Singapore (Lee \& Haque 2006); Statutory bodies as instruments of government in Hong Kong: Review beginnings and analytical challenge ahead (Thynne, 2006) ; and Task Matters: A Structural-Instrumental Analysis of the Autonomy of Hong Kong Government Bodies (Painter \& Yee, 2010).

As regards agencification in Pakistan, empirical case studies conducted by Jadoon, Jabeen, \& Rizwan, (2012) (also part of COBRA project) served as the main literature source. Like in the other two cases, supplementary literature was used. The literature included among others, Agencification in Pakistan: A Comparative Study of Regulatory and Service Delivery Agencies (Jadoon, 2010) ; Agencification of Public Service Delivery in Developing Societies: Experiences of Pakistan and Tanzania Agency Models (Ncukwe \& Adejuwon 2014); and Autonomy of public agencies in Pakistan: does structure matter? (Zahra \& Jadoon, 2016)

The above multiple case studies were treated as literature sources that were used to obtain deeper understanding of the main and supplementary features of respective agencification processes that in turn provided insights into the forms that different cases took as well as complexity.
In addition, the overarching objective of the study was to conduct a comparative analysis of the agencification process in the selected case studies by highlighting similarities and differences among them. That way, the researcher was able to identify the main features that were common and those that were different, across agencification processes in the three case studies. Subsequently, the research was able to draw some lessons from their agencification experiences. As Rihoux \& Ragin, (2009) noted, human reasoning is very much driven by comparison, and went on to suggest that comparison is a key approach in any empirical scientific efforts. Understanding phenomena is facilitated by recognizing and comparing one to others.

Comparative case study approach has been used for a long time in social and political science discipline. Aristotle, conducted a comparative social analysis of constitutions of 184 city-states in Mediterranean, hence considered as one of the pioneers of the approach. However, the systematic comparative study is relatively new, hence has not been that much used (Peters, 1990). Through comparison, political phenomena can be theorized as general preposition (Hopkin, 2010:289).

Following Jreisat (2011), this study studies attributes and performance of administrative systems in order to identify and recognize similarities and differences of agencification process adopted in each case study. Additionally, the study places emphasis on successful or failed practices, thus, guiding alternative strategies for improving administrative reform outcomes.

\section{Comparative Design}

Practically, this study is a crossnational comparative study as it compares several countries and specific institutions at a certain point in time (Figure 1). Thus, it is different from a longitudinal study, which emphasizes time frame (Peters, 1990). During the analysis process, institutions, states, and central processes were combined to have a better understanding of the similarities and differences of the agencification process implemented among them.

Five basic approaches in comparative research are generally used (Fleming, 1970; 


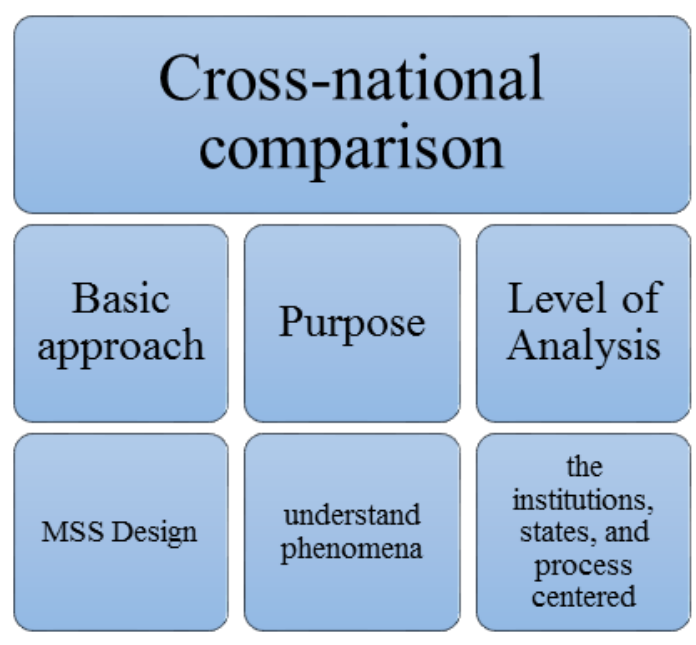

Figure 1. The Comparative Design Anatomy

Hopkin, 2010; Lim, 2010; Peters, 1998)

a. Most Similar System (MSS) design where the locus is countries which have similar features,

b. Most Different System (MDS) design, where the locus entails countries which have different feature except the themes under investigation,

c. Generally Similar Group (GSG) design, where a group of homogenous countries is examined with respect to their group similarities. It is akin to MSS design but without strict modes of MSS.

d. Structural Functional System (SFS) design, the locus lies in emphasis on structural-functional approaches like political structure, culture, and decision-making process.

e. Global Statistical Analysis (GSA) design which uses statistical variable comparison within countries under examination.

Most Similar System (MSS) design is used in analyzing similar jurisdiction in which agencification occurs. Thus, MSS is the most suitable to hold most variables under study relatively constant and thus control for concomitant variation (Peters, 1998)

According to Lim (2010), the purpose of comparison can be categorized into three facets, that include control, understand, and explain. Firstly, comparison is done in order exercise control, which means that the comparison of cases is designated to verify or falsify their hypothesis. Secondly, a comparative study is conducted to understand the phenomena. Lastly, the use of comparative approach is to build stronger theoretical explanation.

Drawing from the rationale of this study, the author primarily aims to understand the phenomena of agencification, so that both academic and practitioners can take some lessons learned from this study. This purpose focuses on interpretation which begins with case selection and use of existing theory to analyze the case study.

\section{RESULTS AND DISCUSSION}

\section{Understanding Agencification}

Agencification has many terms. OECD, (2002) calls it 'distributed public governance'; Pollitt \& Talbot (2003) used the notion of 'unbundled government'; while Overman \& van Thiel (2015) preferred to refer to it as 'semi-autonomous agencies' to address the phenomena. The variety of names of agencification, regardless agencification has been a key feature of NPMoriented public sector reform. The disaggregation from monolithic-centred government bureaucracy to more business-like, lean government agencies is posited to improve efficiency in delivering public services (Hood, 
2001).

The idea of agencification allows governments to divide ministerial and departmental portfolio institutions into smallerdisperse units, which operate at arm's length of government and are responsible for carrying public tasks like education, social welfare, market regulation and other public affairs. The agency model can be distinguished from the traditional bureaucratic model in that it combines expertise, autonomy, and specialisation of tasks in a narrow range of policy issues (Majone, 1997) and characterised by structural devolution but still part of public domain, funded and financed by public (James \& van Thiel, 2010).

Nonetheless, creating a uniform definition of agencification concept is truly a difficult task. This is due to the fact that despite the proliferation agencies, contextual factors that underpin such a process has hampered efforts to create single definition of the concept. In any case, not all type of agencies in many countries fit every case of agencification phenomena.

In practice, differences in administrative systems make standardization of structure of agencies and their procedural system difficult. Nonetheless, there is a common pattern which characterizes most agencification process wherever it occurs. The notion that agencification involves the creation of separate agencies with the goal of implementing a policy or tackling special affairs is supported and accepted by many scholars. In addition, the separate agency is accorded special privilege to operate within a semiautonomous framework.

However, to understand the concept of agencification requires a good understanding of what the agency is. It is widely argued that agencies are at arm's length from the main hierarchical spines of ministries, and carry out public tasks (service provision, regulation, adjudication, and certification) at a national level. Many of them have core staff who are public servants and are financed by the state budget. From the legality perspective, agency is subject to at least some administrative laws (Pollitt et al., 2004).

Trondal (2014:545) defines agency as "an administrative body that is formally separated from a ministerial, or cabinet-level, department and that carries out public tasks at a national level on a permanent basis, is staffed by public servants, is financed mainly by the state budget, and is subject to public legal procedures".

Similarly, Verhoest, Peters, Bouckaert, $\&$ Verschuere (2004) argued that an agency will gain autonomy due to its separation with ministry or central government and is freed from political affluence. They argued that an agency as a structurally disaggregated body is formally separated from the central government. Agency carries out public tasks at the national level on a permanent basis, is staffed by public servants, is financed mainly by the state budget, and is subject to public legal system. However, they also noticed that the agency is not totally independent, because executives normally have ultimate political responsibility for its operations.

In addition, Verhoest et al (2004) statement on characteristic of an agency does not cover agencification in many countries where the operation of agencies is not handled by civil service system, but noncivil service system or those funded by the money mobilized from society. Further, the definition that consider agency to operate at national level is no longer relevant. The agency model now practiced at the local level as well.

Overman \& van Thiel (2015) offered more generic and practically simple exposition by stressing on the structural disaggregation of the structure of the agency from the ministry, carries out public tasks, and operates under more business-like conditions than traditional government bureaucracies. Thus, agencies possess managerial autonomy to shape their own organizational structure and have autonomy in managing their personnel and financial matters.

From the above definition, three main components of agencification which will prominently appeared in the body of literature can be identified. Firstly, the concept of disaggregation refers to the degree of agency that is separated from parent ministries. This component underpins efforts to split up large public sector hierarchies from unitary to multi-firm structures; achieving wider, flatter hierarchies internally; and specifying information and managerial systems lead dif- 
ferent pattern of control (Dunleavy, Margetts, Bastow, \& Tinkler, 2006). By implication agencification induces more flexibility in personnel systems such as recruitment, training, and promotion. "The iron cage of civil service central regulations will be relaxed" (Pollit et al., 2001: 277).

In the broader concept of governance, the agencification phenomena is in accordance to the notion of horizontal governance. Pratikno (2008) stated that horizontalism is inter-organizational relation from governance actors. Drawing from that understanding, disaggregation can also be recognized as some effort to achieve horizontal government. It also leads to the networkedgovernance, rather than hierarchical mechanism.

Secondly, the agency which formally separated from their parent ministries is often subject to regulation by other organization which related with the degree of independence or autonomy. The concept of autonomy or 'autonomization' (Pollitt et al., 2004) designates the degree to which an agency is institutionally separated from parent ministry and whether the agency is given freedom to manage the organization to carry out their tasks and core businesses. The expectation is that autonomy can enhance performance since the public manager is accorded freedom to focus on outcomes rather than procedures, like their counterparts in private organization.

Another argument places the public managers' autonomy as an essential factor to liberalize the conduct of innovations and breakthroughs. There is no doubt that public managers have more formal constraints. higher public expectations. And higher political dynamic influence than private managers (Muchiri, 1999:50)

Furthermore, OECD (2007) contends that autonomy within agencies induces and incentivizes the performance of public sector managers to be output and outcomefocused. Usually, agencies have various degrees of autonomies in carrying out their activities. On a more technical note, some scholars developed dimensions and indicators that are used in examining organizational autonomy such as formal Independence of Regulatory Agencies (Gilardi, 2002) and organizational autonomy map comprises management, policy, structural, financial and interventional autonomy (Verhoest et al., 2012). Nonetheless, while agencies are structurally autonomous, the real autonomy of agencies with respect to performance is still a contested notion.

Thirdly, the separation and degree of autonomy create accountability and control concerns. Thus, the agencification discourse has some bearing to principal-agent theory. Pollitt et al (2004:39) used the terms of 'contractualization' to denote many responsibilities an agent has in carrying out its business core with the specific contract to the parent ministry as the principal in the basis of performance. Under this premise, performance management lies at the center of agencification through such a process, the parent ministry can steer and control their agency in the corpus of accountability. In the modern-democracy context accountability is not only focused on both organizational answerability and macro- sociological level (Wicaksono, 2015). This premise encourages public organizations to seriously posit their public accountability as their substantial agenda.

From the above features, the idealistically and logical explanation of agency encompasses an agency that is separated from parent ministry, and is vested with autonomy which limits political influence within formal contractual or quasi-contractual arrangements. The contract relates to performance management as steering and control gears. This also means that performance management mechanism is used as an accountability mechanism. Besides, some discretion is required in dealing with problems and complexity in operationalization which an agency faces.

According to Massey \& Pyper (2005:85), the agencification process has its strenghts and weaknesess. The upshot of agencification lies in the evolution of an efficient civil service. Whilst, the downside relates to the decline in organizational cohesiveness, which balkanization of service delivery into independent components engenders.

The notion of balkanization is used to denote the breakup of big government and splitting up of public tasks into smaller pieces as independent public bodies that deliver 
public service. This structural issues linked to changes in management as well as the practices resulting from new faces in the government. Consequently, many new public bodies were emerged and changed the government structures as it becomes more decentralized.

A number of model have been developed to explain the rise of agencification. Epistemologically, Pollitt et al (2004: 1231 ) classified the root of agencification as emanating from three streams which include economic or rational choice tradition, traditional social sciences, and constructivist approach.

Rational choice emphasises efficiency as the justification. This relates to a bloated government that is required to undertake economic austerity. It compels governments to cut their budgets and rightsize the bureaucracy. Among the scholars who support the perspective, for instance, encompass the bureau-shaping model, which entails politicians and senior civil servants creating agencies that are aimed at pursuing work-related benefits from different organizational form (Dunleavy, 1991; James, 2003). In the same vein, principal-agent theory, which by and large, argues that agencies will carry out functions that are delegated by principals on the basis of the nature, coverage, and composition of the contract (Molander \& Nilsson, 2002; van Thiel, 2001; van Thiel \& Leeuw, 2002); and delegation theory, which associates agencification with benefits of contributing to political credibility due to the de-politicization and increase of efficiency in decision-making and policy implementation (Majone, 2001).

Traditional social science approach emphasizes empirical regularities. Some of the scholars such as Kickert, (2001) and Pierre (2004) who are scholars of the stream contend that the creation of agencies differs considerably among jurisdictions. That said, efficiency motives have been identified as some of the key drivers. This is borne out by empirical experiences of agencification. The perspective used empirical evidence of agencification to explain the agencification phenomena and its consequences. Strong evidence that is gleaned from empirical research lends support to the notion that is supported by many scholars in public admin- istration who support this school of thought.

Meanwhile, constructivist theories base their analysis on social construction, which includes cultures but not limited to traditions, structures, norms, and values that have significantly influences on the agencification process. The task-specific path dependency model is one of the constructivists approach in agencification research (Pollitt et al., 2004) which challenges both the rational choice and traditional social science approach, arguing that explaining agencification phenomena requires social construction. Social construction and logic underpins the way governments decide to establish an agency is intricately linked to the central inquiry of agencification research.

\section{Comparative Analysis}

After discussing the theoretical framework on the core characteristics and ideal types of agencification, it now the turn to delving into the actual practice and experience of agencification in Thailand, Hong Kong, and Pakistan. The comparative study is accorded special attention landscapes of agencies, history, drivers and characteristics including autonomy and control mechanisms in the public service delivery system (Table $1)$.

\section{Thailand}

Thailand's agencification is inseparable from external factors. In line with structural reform after financial crisis which was facilitated by Iinternational Mmonetary Fund assistance, the first initiative on Thai agencification began in 1999 with the decision of Thai government to borrow the agencification idea and experience from the United Kingdom's executive agencies and New Zealand's crown entities. To that end, the adoption of the idea which has its origin in the United Kingdom and New Zealand implied that Thai administration adopted one form of NPM discipline. This influence began in Thailand in the early 1990s, with the establishment of various quasi-autonomous organizations for public services, including those that were charged with fostering and strengthening the industry competitiveness and capabilities, especially small and medium supporting industries (Lorsuwannarat, 2014). 
Table 1. Comparison of Agencification

\begin{tabular}{|c|c|c|c|}
\hline & Thailand & Hong Kong & Pakistan \\
\hline Initiation & $\begin{array}{l}\text { Autonomous Public Organi- } \\
\text { zation Act of 2542/1999 }\end{array}$ & $\begin{array}{l}\text { Emerged in 1960's with } \\
\text { structural adjustment in } 1997\end{array}$ & $\begin{array}{l}\text { From } 1946 \text { and legally struc- } \\
\text { tured after } 1999\end{array}$ \\
\hline Role Model & UK and New Zealand & UK & UK \\
\hline Landscape & $\begin{array}{l}\text { Growing 2-3 agencies annu- } \\
\text { ally }\end{array}$ & $\begin{array}{l}\text { Growing significantly } 1980 \text { - } \\
1990\end{array}$ & $\begin{array}{l}\text { Growing significantly after } \\
1999\end{array}$ \\
\hline Characteristics & $\begin{array}{l}\text { Driven by political process } \\
\text { Hierarchical accountability }\end{array}$ & $\begin{array}{l}\text { Uphold 'limited government' } \\
\text { principle (rationality) } \\
\text { Less controversy in political } \\
\text { zone }\end{array}$ & $\begin{array}{l}\text { Driven by regime power and } \\
\text { development paradigm } \\
\text { No result-based measure- } \\
\text { ment system }\end{array}$ \\
\hline Autonomy & Low & $\begin{array}{l}\text { Low in financial manage- } \\
\text { ment } \\
\text { High in personnel, operation- } \\
\text { al and strategic policy }\end{array}$ & $\begin{array}{l}\text { Adequate autonomy in per- } \\
\text { sonnel, operational and } \\
\text { managerial }\end{array}$ \\
\hline Control & $\begin{array}{l}\text { Highly control through par- } \\
\text { ent minister }\end{array}$ & $\begin{array}{l}\text { Steering and monitoring } \\
\text { performance }\end{array}$ & $\begin{array}{l}\text { Traditional control by parent } \\
\text { ministry } \\
\text { Absent of performance- } \\
\text { based control }\end{array}$ \\
\hline Contextualization & yes & Yes & yes \\
\hline
\end{tabular}

In Thailand, the agency is called Autonomous Public Organizations (APOs) which are managed by committees or boards. They mainly operate in the fields of education, training and development, art and culture, sports, research and environment, health and social welfare. The establishment of APO does not require approval of the parliament, rather authorization of the King is sufficient. Thus, by eliminating the need for the approval of Thai legislature, the regulation vested the executive arm of government with more authority to establish new APOs. Nonetheless, from the perspective accountability, absence the vital role of parliament in establishing APO signals reducedaccountability.

After one decade, Thai agencification has proliferated as the government has on average been creating at least two to three agencies annually and by 2006 only two agencies have had their operation terminated (Bowornwathana, 2006: 27). The passion to create new APOs emerged when high government officials have a strong motivation to do so. To that end, the process of agencification in Thailand can be described as being based on bureau-shaping model (Dunleavy, 1991). Whenever bureaucrats wish to expand their organizations, new APOs that have new authorities and budget ramifications are established.

Thus, based on the above description, Thai agencification can be described as operationalization of bureaucratization within the agencification. It influences the degree of autonomy and control over APOs. Furthermore, increasing numbers of APOs in Thailand has largely generated more benefits to politicians and high-level bureaucrats than improvement in public service deliveries (Bowornwathana, 2006, 2012).

Moreover, based on research conducted by Lumtanshub (2011) in Verhoest et al., (2012:387), APOs in Thailand used 'Strong Board, Weak CEO' model. In Thailand, the management of APOs consisted of two managerial entities. Based on the locus of accountability, agencies can be distinguished as boards which are accountable to the minister and the Chief Executive Officer (CEO) who is charged of day-to-day APOs' administration. 'Strong Board, weak CEO'model underpins the asymmetrical relationship between board members and CEO in which board members have a stronger influence than CEO in managing APOs. In this case, the hierarchical accountability is very evident, which contrary to NPM principle that requires agencies to conduct their tasks on a contractual basis rather than following the traditional hierarchy. 
However, the Thai government subjects APOs to the same rules, regulations and particular monitoring system that apply to other government organizations. The implication of the above mechanism is that the autonomy of APOs is questionable. In fact, Bowornwathana (2012) calls it as 'Thai-style agencification in a bundled government' which is characterized by the expansion of bureaucracy and not managed at arms-length rather under the arms of parent ministries. Therefore, it is contrary to the ideal type of agencification which involves reducing the size of bureaucratization, emphasizes efficiency and operates under flexibleautonomous features.

Another study conducted by Lorsuwannarat (2014) applied the concepts of agentification of NPM to examine the multidimensions of autonomy and to evaluate the performance of the 9 agencies, with respect to effectiveness, financial self-reliance, and the impact on industrial development. The study used both qualitative and quantitative approaches in collecting data using three focus groups, 37 in-depth interviews, and 3428 questionnaire surveys. Study findings showed that agencification in Thailand generated side effects whenever actors who were involved with the transformation did not always act rationally.

There was no clear-cut division between the central department and the agencies. While the department was expected to transfer its duties to the new agencies, such duties remained under the control and oversight of departments. Thus, the process was plagued by overlapping of duties since the departments continued to carry out similar functions that had ostensibly been transferred to the agencies.

To overcome the problems, Lorsuwannarat (2014) recommended two policy suggestions. Firstly, the need to restructure both organizational structures and the relationship framework between the ministry and the agencies. To eliminate duplication problems, there should be coordination mechanism between ministries and agencies in the conduct of their duties. Secondly, the need for clear policy guidelines to regulate ministries and agencies in conducting their duties and delivering public services.

\section{Hong Kong}

Hong Kong -the city state- was returned to China from British rule in 1997. China adopted 'one country two system' policy in which Hong Kong has its own legal system, police, tax, and budget authority except defence affairs. In fact, the people of Hong Kong have never achieved democracy. Administrative structures are strongly influenced by the British system and wider Commonwealth practices, yet familiar Westminster systems of democratic political control and accountability were not transplanted. However, Hong Kong's bureaucracy has vast experience in automatization and organizational differentiation albeit being centralized and undemocratic government (Painter, 2012: 342).

The notion of agencies is not something new in Hong Kong, and it can be traced to the British administrative system inherited in 1960's. The system is characterized by spate of voluntary associations and business organizations providing service delivery to the society (Painter, 2012; Painter $\&$ Yee, 2010; Thynne, 2006).

The increasing number of agencies in Hong Kong was very evident after 1980 when $60 \%$ of existing bodies were created. To that end, the above phenomena corroborates the argument that NPM has led the proliferation of agencies in terms of numbers and types (James, 2003). From the autonomy perspective, Hong Kong has enjoyed autonomous agencies. Based on the COBRA online survey of 111 government bodies which are product of agencification, attest to the existence and achievement of autonomy. Nonetheless, autonomy of agencies varied by function with lowest autonomy identified in financial management and higher autonomy found in realms of personnel, operational, and strategic policy.

The above condition is attributable to the fact that Hong Kong government laid emphasis on budgeting and financing the delivery of public services (Cheung, 2006) motivated by the need to maintain low tax regime. In addition, the high participation of voluntary associations and business organizations which is a legacy of British administrative system also help to enhance the autonomy of agencies.

Another explanation is attributed to 
Painter \& Yee (2010). In their work, they used the structural-instrumental analysis to study the Autonomy of Hong Kong Government Bodies. The study used data that were obtained from a survey of perceptions about autonomy of agencies of chief executives of 111 Hong Kong government agencies, the study explored a series of propositions on the relationships between structure, task, and perceived autonomy.

In their study Painter \& Yee (2010) determined that explaining the degree of autonomy of agencies required analyzing structure and task as variables. However, public service delivery organizations face tighter, not looser control, while regulatory agencies show no tendency becoming more autonomous. The inference that can draw from this is that Hong Kong's constitutional and political history underscore the importance of contextualization in the implementation of agencification.

As a contract-based organization, an agency is closely bounded by performance measurement. To control the agencies, performance measurement framework was put in place and entailed such mechanism as target-based management and performance measurement system. Thus, in the perspective of principal-agent theory, the Hong Kong context fall in the category of an ideal practice. Another important facet of agencification in Hong Kong is that the government maintained lean government, making the agencification not a contentious issue. Agencies are charged with carrying out both political and administrative roles (Painter, 2012:350).

This argument corroborates with Lee \& Haque (2006) who compare the NPMbased Reform and governance in Hong Kong and Singapore. The conclusion drawn was that political regimes contributed to shaping NPM reforms the polities implemented with defining features including macroeconomics, political systems, and traditions.

\section{Pakistan}

Pakistan is one of the former British colonies in South Asia which have implemented agencification. Like Hong Kong, agency is also not something new to Pakistan. Pakistan bequeathed many agencies from the colonial era (Jadoon, 2010). Narrated in national good governance doctrines, the structural adjustment commenced in 1999. During this period, agencies were dominated new-specific task and public service deliveries in areas of health, education, training, and research, among other.

According to Jadoon et al. (2012), agencification in Pakistan mirrored the history of Country's development and it can be divided into 4 phases. The four phases include development administration (19471971), development enterprise (1972-1977), development management (1977-1999), and development governance (1999-2010). The agencification landscapes was influenced by the development paradigm Pakistan adopted in each phase and period. However, the development governance era (1999-2010) has the largest number of agencies created (70 agencies). Of the 70 agencies that were established during 1999-2010, 15 were regulatory bodies.

With regards to the external influence that bore to agencification in Pakistan, Ncukwe \& Adejuwon (2014) argued that Pakistan's agencification was influenced by policy guidance of the World Bank. Thus, international pressure, in part palyed a role in the nature, number, and the structure of public sector agencies that created which followed similar guidelines to other part of the world.

The autonomy of agencies depends on their type of legal-structure. Semiautonomous agencies have a significant level of managerial autonomy but lack of legal identity. Moreover, policy control was formally vested in the federal government with agencies under tutelage of the minister. To that end, the span of control went to the minister of the parent ministry, through the prime minister and ultimately to the national parliament. "...all semi-autonomous bodies and autonomous bodies are expected to submit their annual reports to their parent ministries"(Jadoon et al., 2012: 379). Under the scheme, agencification which was adopted in Pakistan was characterized by traditionalhierarchical accountability. Thus, the span of control and accountability affected agency's autonomy, even though the administration of the agency had managerial flexibility.

From the rational choice perspective, 
Zahra \& Jadoon (2016) examined the relationship between structural arrangements of Pakistan public agencies and their autonomy they enjoy. The study was based on a questionnaire that involved the key informants from 70 public agencies of Pakistan.

Research results identified structural dimensions, horizontal specialization, vertical specialization and the governing board as key variables. It is only governing board that was found to have influenced on the autonomy of human resource management dimension while vertical specialization bear relation to autonomy in the realm of financial management. Results did not support any one of the three hypotheses entirely. Meanwhile, results from the structural instrumental perspective indicated the importance of other factors related to agencies that include administrative culture and context of state.

The agencification process in Pakistan was implemented under an administrative system that had weak political institutions but a strong entrenched bureaucracy. The strong wave of the bureaucratization can be traced to the features of strong colonial bureaucratic traditions that was manifested by the centralization of power exercised by a certain class of senior bureaucrats. By and large, such bureaucrats, occupy top positions in federal ministries.

From the three case studies, an inference can be made that there are similarities, variations and diverse pathways of agencification adopted in three countries. Two similarities stand out in three cases. Firstly, agencification adopted in three countries was influenced by Anglo-Saxon model with the apogee of agency proliferation occurring during NPM heydays after the 1980s. Secondly, context matter in shaping and influencing agencification process in the three countries.

However, there were variations in terms of initiation, characteristics, autonomy and control among these countries. In Thailand, agencification came into force under Act Number 2542/1999, while both Hong Kong and Pakistan as former British colonies, agencification was already underway prior to attaining their independence and incorporated into legal structure during 1990's. The characteristic of agencification in Thailand was driven by political process and had hierarchical accountability. Meanwhile, agencification adopted in Hong Kong was characterized by focus on rationality, hence was devoid political contentions. Pakistan had also different features influenced by the regime in power and very much in line with the trajectory of development paradigm at the time. Further Pakistan agencification was not based on result-based measurement system.

Agencification process in Hong Kong was characterized by autonomy in personnel, operations and strategic policy, but limited financial autonomy. Agencification in Pakistan enjoyed personnel, operational and managerial autonomy. Finally, agencification in Thailand had the lowest autonomy.

\section{What can Indonesia learn from experienc- es of the three countries?}

Agencification refers to the process of transferring policies from one jurisdiction to another, Moynihan (2006) identified three processes of interpretation for policymakers. The three process include (1) adopt superficially similar policy concepts; (2) overlook negative experiential learning; and (3) adopt policies unsuitable to the national context. He argued that agencification is plagued by policy ambiguity, which explains varying success across countries that adopt it, with some registering success while others fail. By examining agencification phenomena in the case studies, policy makers are able to adopt policies that fits their respective environment have the ability evaluate negative experiences which in the end enables them to determine what works and what doesn't.

Reflecting on experiences of three countries, public administration scholars as well as practitioners can draw some lessons learned in agencification process.

Firstly, the rational agency model is not the only driver of agencification. The ideal suggestions from rational agency model are not easy to implement in the actual practices. Thus, other motives such as traditions, structures, and political values play an important role in agencification process.

Secondly, agencification cannot guarantee agency's autonomy. One of the agencification objectives is to ensure the autonomy of agency, reduce political influence and im- 
prove performance in public service deliveries. However, the experience from Thailand and Pakistan showed us that agencification does not always ensure expected autonomy that is required to increase performance.

Thirdly, the ideal type of agencification which should emphasis contract-based performance is not always attainable due to the retention of control by parent ministry. This implies hierarchical accountability continues to be the key mechanism that links the agency to the parent organization. Thus, the agency is not assessed based on performance but political interest.

Fourthly, referring to the experience of Hong Kong agencification that is based on performance and characterized by limited political interest generate more positive outcomes than where the process is not based on performance and plague strong political intervention. Thus, agencification should involve the development of performance management system as well as minimize political intervention in its operation and management.

Fifthly, the bureau-shaping model (Dunleavy, 1991; James, 2003) in agencification initiatives which is motivated by the desire of bureaucrats to enlarge the bureaucracy structure as well as budget and authorities does not lead to the improvement in the quality of governance but increase government burden.

Sixthly, the importance of 'contextualization' in adopting foreign-based public sector reforms (such as agencification) need to be considered to minimize unintended consequences. Culture and localism play important roles in shaping public sector reform process.

\section{CONCLUSION}

To sum up, it can be argued that three countries have implemented agencification in different ways. In terms of agencification motives, the rational agency model is not the only driver of agencification but, equally important is the constructivist model which posit the importance of traditions, structures, and values in agencification process. Simply put, agencification process is not living in a vacuum, rather its implementation entails an interplay of politics and administrative environments to shape the implementation process.

Unlike Hong Kong which adopted performance based agencification characterized by limited political intervention, both Thailand and Pakistan are still struggling with performance issues, modes of accountability, and political obstacles.

Lastly, this analysis which captured the condition based on various empirical research does have one limitation, which is that its findings can not generalized to all Asian countries that face different settings.

\section{REFERENCES}

Bowornwathana, B. (2006). Autonomisation of the Thai state: Some observations. Public Administration and Development, 26(1), 27-34. http:// doi.org/10.1002/pad.368

Bowornwathana, B. (2012). Thailand. In K. Verhoest, S. van Thiel, A. Smullen, \& P. Lægreid (Eds.), Government Agencies. Practices and Lessons from 30 Countries. Basingstoke.

BUSUIOC, E. M. (2016). Friend or Foe? Inter-Agency Cooperation, Organizational Reputation, and Turf. Public Administration, 94(1), 40-56. http:// doi.org/10.1111/padm.12160

Cheung, a. B. L. (2006). Budgetary reforms in two city states: impact on the central budget agency in Hong Kong and Singapore. International Review of $\mathrm{Ad}$ ministrative Sciences, 72(3), 341-361. http:// doi.org/10.1177/0020852306068013

Dunleavy, P. (1991). Democracy, Bureaucracy and Public Choice: Economic Explanation in Political Sciences. Hemel Hempstead: Harvester Wheatsheaf.

Dunleavy, P., Margetts, H., Bastow, S., \& Tinkler, J. (2006). New public management is dead - Long live digital-era governance. Journal of Public Administration Research and Theory, 16(3), 467-494. http://doi.org/10.1093/jopart/ mui057

Egeberg, M., \& Trondal, J. (2016). Agencification of the European Union Administration Connecting the Dots.

Fleming, W. G. (1970). The Logic of Com- 
parative Social Inquiry. By Przeworski Adam and Teune Henry. (New York: John Wiley and Sons, Inc., 1970. Pp. 153. \$8.50.). American Political Science Review, 64(4), 1255-1256. http:// doi.org/10.2307/1958372

Gilardi, F. (2002). Policy credibility and delegation to independent regulatory agencies: a comparative empirical analysis. Journal of European Public Policy, 9 (6), 873-893. http:// doi.org/10.1080/135017602200004640 9

Guy Peters, B. (1990). The Necessity and Difficulty of Comparison in Public Administration. A sian Journal of Public Administration, 12(1), 3-28. http:// doi.org/10.1080/02598272.1990.10800 226

Haque, M. S. (2013). Globalization, State Formation, and Reinvention in Public Governance: Exploring the Linkages and Patterns in Southeast Asia. Public Organization Review, 13(4), 381-396. http://doi.org/10.1007/s11115-0130258-3

Hood, C. (2001). A PUBLIC MANAGEMENT FOR ALL SEASONS? Public Administration, 69(1). http:// doi.org/10.1111/j.14679299.1991.tb00779.x

Hopkin, J. (2010). Comparative Method. In D. Marsh \& G. Stoker (Eds.), Theory and methods in political science. Basingstoke: Palgrave Mac Millan.

Jadoon, M. Z. I. (2010). Agencification in Pakistan: A Comparative Study of Regulatory and Service Delivery Agencies.

Jadoon, M. Z. I., Jabeen, N., \& Rizwan, A. (2012). Pakistan. In K. Verhoest, S. van Thiel, G. Bouckaert, \& P. Lægreid (Eds.), Government A gencies. Practices and Lessons from 30 Countries. Basingstoke.

James, O. (2003). The Executive Agency Revolution in Whitehall. Basingstoke: Palgrave Mac Millan.

James, O., \& van Thiel, S. (2010). Structural Devolution to Agencies. In T. Christensen \& P. Lægreid (Eds.), The Ashgate Research Companion to New Public Management. Surrey: Ashgate.

Jordana, J., Levi-Faur, D., \& i Marin, X. F.
(2011). The Global Diffusion of Regulatory Agencies: Channels of Transfer and Stages of Diffusion. Comparative Political Studies, 44(10), 1343-1369. http:// doi.org/10.1177/0010414011407466

Jreisat, J. (2011). Globalism and Comparative Public Administration. Statewide Agricultural Land Use Baseline 2015 (Vol. 1). http://doi.org/10.1017/ CBO9781107415324.004

Kickert, W. J. M. (2001). Management of Hybrid Organizations: Governance of Quasi - Autonomous Executive Agencies. International Public Management Journal, 4, 135-150.

Lam, W. F. (2005). Coordinating the government bureaucracy in Hong Kong: An institutional analysis. Governance, 18(4), 633-654. http://doi.org/10.1111/ j.1468-0491.2005.00295.x

Lee, E. W. Y., \& Haque, M. S. (2006). The new public management reform and governance in Asian NICs: A comparison of Hong Kong and Singapore. Governance, 19(4), 605-626. http:// doi.org/10.1111/j.14680491.2006.00330.x

Lim, T. (2010). Introduction: What is Comparative Politics? Doing Comparative Politics : An Introduction to Approaches and Issues.

Lorsuwannarat, T. (2014). Autonomy and Performance of Agentification: Cases of Nine Independent Agencies in Thailand. Journal of US-CHina Public Administration, 11(10), 797-815. http:// doi.org/10.17265/15486591/2014.10.001

Majone, G. (1997). From the positive to the regulatory state: Causes and consequences of changes in the mode of governance. Journal of Public Policy, 17 (2), 139. http://doi.org/10.1017/ S0143814X00003524

Majone, G. (2001). Two logics of delegation: agency and fiduciary relations in EU governance. European Union Politics, 2(1).

Massey, A., \& Pyper, R. (2005). Public Management and Modernisation in Britain. New York: Palgrave Mac Millan. 
Molander, P., \& Nilsson, J. (2002). Does anyone govern? The relationship between the Government Office and the agencies in Sweden.

Moynihan, D. P. (2006). Ambiguity in Policy Lessons: The Agentification Experience. Public Administration, 84(4), 1029-1050. http://doi.org/10.1111/ j.1467-9299.2006.00625.x

Muchiri, M. (1999). The role of transformational leadership to reengineering public administration in the future. Jurnal Kebijakan Dan Administrasi Publik, 3 (2), 41-66.

Ncukwe, F., \& Adejuwon, K. (2014). Agencification of Public Service Delivery in Developing Societies: Experiences of Pakistan and Tanzania Agency Models. Africa's Public Service Delivery and Performance Review, 2(3), 106 $-124$.

OECD (Organisation for Economic Cooperation and Development). (2007). Distributed Public Governance.

Ongaro, E., Barbieri, E., Belle, D., \& Fedele, P. (2012). European Union Agencies. In Government Agencies. Practices and Lessons from 30 Countries. Basingstoke: Palgrave Mac Millan.

Overman, S., \& van Thiel, S. (2015). Agencification and Public Sector Performance: A systematic comparison in 20 countries. Public Management Review, 9037(September), 1-25. http:// doi.org/10.1080/14719037.2015.10289 73

Painter, M. (2012). Hongkong. In K. Verhoest, S. van Thiel, G. Bouckaert, \& P. Lægreid (Eds.), Government Agencies. Practices and Lessons from 30 Countries. Basingstoke: Palgrave Mac Millan.

Painter, M., \& Yee, W.-H. (2010). Task Matters: A Structural-Instrumental Analysis of the Autonomy of Hong Kong Government Bodies. The American Review of Public Administration, 41(4), 395-410. http:// doi.org/10.1177/0275074010380451

Peters, B. G. (1998). Comparative politics: Theory and methods. New York: NYU Press.

Pierre, J. (2004). Central Agency in Sweden a Report from utopia. In C. Pollitt \& C. Talbot (Eds.), Unbundled Government. London: Roudledge.

Pollit, C., Bathgate, K., Caulfield, J., Smullen, A., \& Talbot, C. (2001). Agency fever? Analysis of an international policy fashion. Journal of Comparative Policy Analysis: Research and Practice, 3 (3), 271-290. http:// doi.org/10.1080/13876980108412663

Pollitt, C., \& Talbot, C. (2003). Unbundled Government: A Critical Analysis of the Global Trend to Agencies, Quangos and Contractualisation. London: Roudledge.

Pollitt, C., Talbot, C., Caulfield, C., \& Smullen, A. (2004). Agencies: How Governments Do Things Through SemiAutonomous Organizations. Basingstoke: Palgrave Mac Millan.

Pratikno. (2008). Manajemen jaringan dalam perspektif strukturasi. Jurnal Kebijakan Dan Administrasi Publik, 12(1), 1-19.

Rihoux, B., \& Ragin, C. (2009). Configurational Comparative Methods Qualitative Comparative Analysis (QCA) and Related Techniques. London: SAGE.

Smullen, A. (2007). Translating agency reform. Rhetoric and culture in comparative perspective. Public Management. http://doi.org/10.1057/9780230289703

Study, C., \& Agencies, S. D. (2010). Agencification in Pakistan: A Comparative Study of Regulatory and Service Delivery Agencies

Thynne, I. (2006). Statutory bodies as instruments of government in Hong Kong: Review beginnings and analytical challenge ahead. Public Administration and Development, 26(1), 45-53. http:// doi.org/10.1002/pad.367

Trondal, J. (2014). Book Review: Government Agencies: Practices and Lessons from 30 Countries. Public Administration Review, 74(4), 545-549. http:// doi.org/10.1111/puar.12252.Book

van Thiel, S. (2001). Quangos: Trends, Causes and Consequences. Aldershot: Ashgate.

van Thiel, S., \& Leeuw, F. L. (2002). The Performance Paradox in the Public Sector. Public Performance \& Management Review, 25(3), 267-281. http:// 
Arif Pratama - Agencification in Asia: Lessons from Thailand, Hong Kong, and Pakistan....

doi.org/10.2307/3381236

Verhoest, K., Peters, B. G., Bouckaert, G., \& Verschuere, B. (2004). The study of organisational autonomy: A conceptual review. Public Administration and Development, 24(2), 101-118. http:// doi.org/10.1002/pad.316

Verhoest, K., van Thiel, S., Bouckaert, G., \& Lægreid, P. (2012). Government Agencies. Practices and Lessons from 30 Countries. Basingstoke: Palgrave Mac Millan.

Wettenhall, R. (2005). Agencies and nondepartmental public bodies. Public Management Review, 7(4), 615-635. http://

doi.org/10.1080/14719030500362827
Wicaksono, K. W. (2015). Akuntabilitas Organisasi Sektor Publik. Jurnal $\mathrm{Ke}$ bijakan Dan Administrasi Publik, 19 (1), 3-12.

Zahra, A., \& Jadoon, M. Z. I. (2016). Autonomy of public agencies in Pakistan: does structure matter? International Journal of Public Sector Management, 29(6), 565-581. http://doi.org/10.1108/ IJPSM-02-2015-0019 